\title{
A meta-analysis of the epidemiology of giant cell arteritis across time and space
}

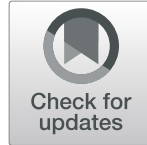

Katherine J. $\mathrm{Li}^{1 \dagger}$, Daniel Semenov ${ }^{1 \dagger}$, Matthew Turk ${ }^{2}$ and Janet Pope ${ }^{1 *}$ (D)

\begin{abstract}
Introduction: Giant cell arteritis (GCA) is a common large vessel vasculitis in those over age 50 years. This metaanalysis examined the geographical and temporal distribution of the incidence, prevalence, and mortality of GCA.

Methods: A systematic review was conducted using EMBASE, Scopus, and PubMed from their inceptions until 2019. Studies were included if they reported at least 50 or more GCA patients and defined the location and time frame. Articles on mortality were included and standardized mortality ratio (SMR) was extracted where possible. Mean pooled prevalence, incidence, and SMR were calculated using a random effects model. Linear regression was used to explore correlations between latitude and incidence, prevalence, and mortality.

Results: Of the 3569 citations identified, 107 were included. The pooled incidence of GCA was 10.00 [9.22, 10.78] cases per 100,000 people over 50 years old. This incidence was highest in Scandinavia 21.57 [18.90, 24.23], followed by North and South America 10.89 [8.78, 13.00], Europe 7.26 [6.05, 8.47], and Oceania 7.85 [- 1.48, 17.19]. Pooled prevalence was $51.74[42.04,61.43]$ cases per 100,000 people over age 50. Annual mortality was $20.44[17.84,23.03]$ deaths/1000. Mortality generally decreased over the years of publication $(p=0.0008)$. Latitude correlated significantly with incidence $(p=0.0011)$, but not with prevalence, or mortality.
\end{abstract}

Conclusions: GCA incidence varies nearly 3-fold between regions and is highest in Scandinavia but not significantly. Mortality may be improving over time.

Keywords: GCA, Giant cell arteritis, Temporal arteritis, Meta-analysis, Epidemiology, Geographic variation, Temporal trend, Mortality, Prevalence, Incidence

\section{Key messages}

- Certain regions have a disproportionate burden of giant cell arteritis (GCA), and the mechanism is not fully understood.

- Latitude influences the distribution of some autoimmune conditions, however, not GCA.

- Despite increasing average age of GCA, increasing GCA rates were not found.

\footnotetext{
* Correspondence: janet.pope@sjhc.london.on.ca

${ }^{\dagger}$ Katherine J. Li and Daniel Semenov contributed equally to this work. 'Schulich School of Medicine, University of Western Ontario, St. Joseph's Health Care, 268 Grosvenor St, D2 Rheumatology, London, ON N6A 4V2, Canada

Full list of author information is available at the end of the article
}

\section{Introduction}

Giant cell arteritis (GCA) is a polygenic immunemediated disease of unknown etiology that occurs in individuals aged 50 years and older [1]. It is thought to be caused by exaggerated immune responses to vascular endothelial injury with lymphocyte proliferation and giant cell formation. These responses lead to luminal narrowing and disruption of the internal elastic lamina, which limit blood flow and cause end organ ischemia [2]. Common symptoms include headache, scalp tenderness, jaw claudication, and visual loss. GCA is classified using the 1990 ACR criteria, and though a histological diagnosis is preferred, a positive temporal artery biopsy (TAB) is not mandated [3]. Diagnoses may be confirmed without a

C C The Author(s). 2021 Open Access This article is licensed under a Creative Commons Attribution 4.0 International License, which permits use, sharing, adaptation, distribution and reproduction in any medium or format, as long as you give appropriate credit to the original author(s) and the source, provide a link to the Creative Commons licence, and indicate if changes were made. The images or other third party material in this article are included in the article's Creative Commons licence, unless indicated otherwise in a credit line to the material. If material is not included in the article's Creative Commons licence and your intended use is not permitted by statutory regulation or exceeds the permitted use, you will need to obtain permission directly from the copyright holder. To view a copy of this licence, visit http://creativecommons.org/licenses/by/4.0/ The Creative Commons Public Domain Dedication waiver (http://creativecommons.org/publicdomain/zero/1.0/) applies to the data made available in this article, unless otherwise stated in a credit line to the data. 
positive biopsy and imaging is sometimes used such as temporal artery ultrasound.

GCA is a common systemic vasculitis in adults and is closely associated with polymyalgia rheumatica (PMR); approximately $40-60 \%$ of patients with GCA have PMR while $15-20 \%$ of those with PMR develop GCA symptoms [4].

The epidemiology of GCA has been extensively studied. The average age of diagnosis has increased from 75 in the 1950s to 79 in the 2000s [5]. GCA has also more common in females at a ratio of 2.5:1 [1, 6]. Incidence has consistently been found to be highest in Scandinavia and lowest in Asian countries [1]. Some autoimmune disorders such as multiple sclerosis have shown latitudeassociated trends [7]. GCA may be increased in northern latitudes. Seasonal and temporal clustering of incident GCA have been reported, perhaps due to viral triggers; however, this relationship remains unclear [1].

As the population continues to age, the incidence, prevalence, and mortality of GCA are expected to increase. Considering the significant morbidity associated with GCA from blindness, aortic defects, and treatment, a better understanding of the changing epidemiology is needed.

The last major epidemiological meta-analysis of GCA was published in 2008 [8]. Our study aimed to provide a comprehensive update on the global geographic and temporal trends for incidence, prevalence, and mortality in GCA, and examine its potential connection with latitude.

\section{Methods}

\section{Study selection}

A systematic review of the literature was performed to identify studies examining the incidence, prevalence, or mortality of GCA. EMBASE, Scopus, and PubMed were searched from their inceptions until February 2019. Our search strategy is reported in Supplementary Table 1. Studies were included if they were written in English, presented a cohort or cross-sectional data on more than 50 patients with GCA and reported on population, location and/or time-frame parameters. Articles on mortality were included as a rate, and if they provided an age- and gendermatched population (Standardized Mortality Ratio), that was also extracted. Review articles, case-control studies, and case series were excluded. Study quality was assessed by using the Strengthening the Reporting of Observational Studies in Epidemiology (STROBE) checklist (Supplementary Table 2).

\section{Data extraction and analysis}

The following data were extracted from each study: year of publication, study country, total number of GCA cases, years of cohort, number of deaths, incidence, prevalence, and mortality rate. Mortality rate was standardized across cohorts to deaths per 1000 people per year. The website www.latlong.net was used to determine the latitude of the population location (city or region) examined in each included article. Forest plots were generated using Revman5.3 to determine the pooled incidence, prevalence, and mortality using Wilson's score method. The $95 \%$ confidence intervals were generated using a random effects model to account for differences in variance and quality between studies. Tau squared statistics were used to evaluate heterogeneity between studies. Publication bias was assessed using funnel plots, which were also generated on Revman5.3. Linear regression was used to evaluate temporal and geographic differences using SPSS26 where $p<0.05$ was significant.

\section{Results \\ Search results}

The search identified 5426 articles of which 107 were included for analysis (Fig. 1). There were 3578 duplicates between databases and 1741 did not meet eligibility criteria. Table 1 provides the information on the studies extracted and the incidence, prevalence, and mortality from each paper. The study quality as measured by the STROBE instrument is found in Table 1. There was some evidence of publication bias according to funnel plots (Supplementary Fig. 1).

\section{Incidence}

Of the 107 studies, 61 studies reported on the incidence of GCA. Studies were sorted into several geographic areas and pooled incidence was calculated per 100,000 people over 50 years (Fig. 2). The included geographic areas from highest to lowest incidence [95\% CI] were Scandinavia 21.57 [18.90, 24.23], North and South America 10.89 [8.78, 13.00], Oceania 7.85 $[1.48,17.19]$, Europe $7.26[6.05,8.47]$, Middle East $5.73[4.20,7.26]$, Africa $4.62[0.05,9.20]$, and East Asia $0.34[0.12,0.56]$. The highest incidence within the studies was in Denmark $76.6[54.65,98.55]$ and the lowest was in Hong Kong 0.34 [0.12, 0.56]. The global pooled incidence was 10 [9.22, 10.78] per 100,000 people over 50 years. Global incidence rates were visually plotted on a map (Supplementary Fig. 2).

Incidence was also assessed across publication years using linear regression. Scandinavia had the largest decreasing incidence rate. Incidence decreased by 0.80 per 100,000 people per year, corresponding to a reduction of two-thirds between $1981(42.3$ per 100,000) and 2017 (13.4 per 100,000) $\left(R^{2}=0.58, p=0.029\right)$. Globally, pooled incidence decreased over time at a rate of 0.41 per 100,000 per year $\left(R^{2}=0.27, p=0.034\right)$. 


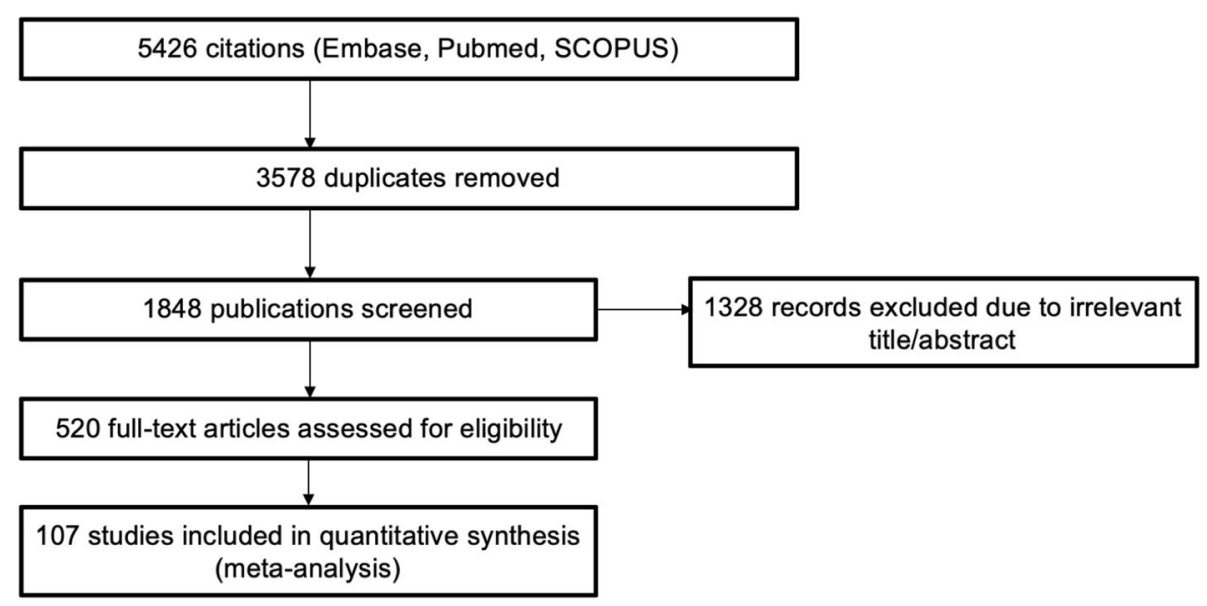

Fig. 1 Flow chart of study selection. The flow chart was developed using PRISMA: Preferred Reporting Items for Systematic Reviews and Meta-Analyses

\section{Prevalence}

A total of 9 studies reported on the prevalence of giant cell arteritis. The overall pooled prevalence was 51.74 [42.04, 61.43] cases per 100,000 people over 50 years (Fig. 3). The prevalence was stable across publication years of the studies using a linear fit model.

\section{Mortality}

Thirty-seven articles included data on mortality. The overall pooled mortality rate is 20.44 [17.84, 23.03] cases per 1000 people over 50 years (Fig. 4). Highest mortality was in Hong Kong (52.63) with lowest in the USA (34.09). Across publication years, there was an overall decrease in mortality over time with a rate of 0.14 per 1000 people per year $(p=0.00076)$.

\section{Latitude}

Incidence, prevalence, and longitude were plotted against absolute latitude and were assessed using linear regression (Fig. 5). The $\mathrm{R}$ squared value for incidence, prevalence, and mortality was 0.1657, 0.1358, and 0.0002 . Our linear model only showed a significant correlation between latitude and incidence $(p=0.0011$, beta $=$ $0.489)$, not prevalence $(p=0.33)$ or mortality $(p=0.92)$.

\section{Discussion}

The incidence of GCA was threefold higher in Scandinavia relative to the rest of Europe and was 6 times higher in Scandinavia compared to East Asia. The high incidence rates of GCA in parts of North America may be explained by communities with Scandinavian ancestry, such as in Olmsted County, USA [9]. This could disproportionately elevate the overall incidence of GCA in North America, with a rate exceeding most regions (except Scandinavia). These findings are consistent with those previously reported $[1,8,10-13]$.

The increased incidence of GCA in Scandinavian countries may be explained by genetic susceptibility. Patients with GCA have haplotype variation in certain MHC class II alleles, with a predominance of HLA DRB1*04 specifically. Polymorphisms in genes expressing inflammatory mediators such as TNF, adhesion molecules, and IL18 are sometimes implicated in GCA $[1,14]$. In addition, rates could be higher in Scandinavia due to more advanced healthcare tracking systems [15]. Seasonal variations have also been reported, albeit with low statistical power [1]. It is also speculated that microorganisms may trigger infections and lead to immunemediated hypersensitivity, although evidence for this remains controversial [16].

Our results found that there was only a statistically significant association between latitude and incidence, not prevalence or mortality. However, regional differences may exist due to variations in population concentration; urban populations tend to have higher incidence rates of GCA compared to rural regions [17]. This trend is possibly explained by proximity to medical centers with greater diagnostic capacity and higher surrounding patient concentrations [17]. It is not correct to assume that latitude is associated with increased incidence due to HLA gene concentrations in Scandinavian countries. While Scandinavian countries have both high concentrations of HLADRB ${ }^{*} 04$ and high latitudes, they are independently associated with the incidence of GCA in both univariate and multivariate models [18]. It is paradoxical that incidence was associated with latitude whereas prevalence was not. The discrepancy between the two likely lies in the statistical power of our prevalence model; as only 9 studies reported on prevalence of GCA 
Table 1 Characteristics and research quality of studies reporting the incidence (average per 100,000 over 50 years old), prevalence (average per 100,000 over 50 years old) and mortality (average per 1000 people over 50 years of age) of GCA

\begin{tabular}{|c|c|c|c|c|c|c|c|}
\hline Epidemiological study category & First author (citation) & Year & Location & Latitude $\left({ }^{\circ} \mathrm{N}\right)$ & STROBE & Total patients & Rate \\
\hline Mortality & Andersson $\mathrm{R}$ & 1986 & Sweden & 57.71 & 20 & 90 & 29.17 \\
\hline Mortality & Baslund B & 2014 & Denmark & 55.33 & 21 & 1787 & 26.3 \\
\hline Mortality & Belvedere LM & 2016 & Italy & 49.28 & - & 280 & 21.84 \\
\hline Mortality & Bengtsson BA & 1981 & Sweden & 57.70 & 17 & 90 & 28.89 \\
\hline Mortality & Bisgard C & 1991 & Denmark & 56.36 & 18 & 34 & 40.72 \\
\hline Mortality & Boesen P & 1987 & Denmark & 55.33 & 18 & 46 & 27.17 \\
\hline Mortality & Brekke LK & 2015 & Norway & 60.39 & - & 820 & 13.51 \\
\hline Mortality & Brekke LK & 2016 & Norway & 60.39 & - & 820 & 13.81 \\
\hline Mortality & Catanoso M & 2014 & Italy & 44.70 & - & 285 & 15.59 \\
\hline Mortality & Catanoso M & 2017 & Italy & 44.70 & 19 & 285 & 16.76 \\
\hline Mortality & Crow R & 2009 & USA & 40.76 & 21 & 44 & 34.09 \\
\hline Mortality & Diamantopoulos AP & 2014 & Norway & 58.14 & 22 & 212 & 18.87 \\
\hline Mortality & Graham E & 1981 & UK & 51.51 & 18 & 90 & 35.56 \\
\hline Mortality & Gran JT & 2001 & Norway & 58.83 & 20 & 338 & 20.41 \\
\hline Mortality & Hachulla E & 2001 & France & 50.63 & 19 & 133 & 17.13 \\
\hline Mortality & Hernandez-Rodriguez J & 2002 & Spain & 41.39 & 19 & 75 & 12.38 \\
\hline Mortality & Huston KA & 1978 & USA & 43.83 & 21 & 42 & 20 \\
\hline Mortality & Khalifa M & 2009 & Tunisia & 35.83 & 20 & 96 & 2.45 \\
\hline Mortality & Knorring J & 1979 & Finland & 60.17 & 15 & 53 & 15.09 \\
\hline Mortality & Kobayashi S & 2003 & Japan & 35.69 & 21 & 66 & 45.45 \\
\hline Mortality & Labarca C & 2015 & USA & 43.16 & 21 & 286 & 16.08 \\
\hline Mortality & Lie JT & 1995 & USA & 38.58 & 19 & 72 & 10 \\
\hline Mortality & $\operatorname{Lin} L$ & 2018 & UK & 55.90 & 22 & 9778 & 14.58 \\
\hline Mortality & Macchioni P & 2018 & Italy & 44.70 & 22 & 281 & 7.94 \\
\hline Mortality & Matteson EL & 1996 & USA & 43.83 & 20 & 214 & 19.08 \\
\hline Mortality & Mohammad A & 2011 & Sweden & 55.99 & 22 & 792 & 24.38 \\
\hline Mortality & Mohammad AJ & 2015 & Sweden & 55.99 & 22 & 840 & 25.55 \\
\hline Mortality & Moinet $F$ & 2017 & Martinique & 14.60 & - & 40 & 6 \\
\hline Mortality & Ninan J & 2011 & Australia & -34.93 & 20 & 225 & 22.54 \\
\hline Mortality & Nordborg E & 1989 & Sweden & 57.70 & 20 & 284 & 28.87 \\
\hline Mortality & Pamuk ON & 2009 & Turkey & 41.68 & 21 & 19 & 35.09 \\
\hline Mortality & Pierluigi M & 2016 & Italy & 44.70 & - & 280 & 16.33 \\
\hline Mortality & Pierluigi M & 2018 & Italy & 44.70 & 21 & 285 & 21.84 \\
\hline Mortality & Rajala S & 1993 & Finland & 61.50 & 19 & 66 & 22.73 \\
\hline Mortality & Tam S & 2008 & Hong Kong & 22.40 & 21 & 19 & 52.63 \\
\hline Mortality & Whitfeild AG & 1963 & UK & 52.63 & 10 & 72 & 13.89 \\
\hline Mortality & Yates M & 2013 & UK & 52.63 & 21 & 119 & 21.01 \\
\hline Prevalence & Boesen P & 1987 & Denmark & 55.33 & 18 & 46 & 135 \\
\hline Prevalence & Catanoso M & 2017 & Italy & 44.70 & 20 & 285 & 87.9 \\
\hline Prevalence & Crowson CS & 2016 & USA & 43.83 & 20 & 248 & 204 \\
\hline Prevalence & Herlyn K & 2014 & Germany & 53.87 & 20 & 150 & 44 \\
\hline Prevalence & Khalifa M & 2009 & Tunisia & 35.83 & 18 & 96 & 7 \\
\hline Prevalence & Kobayashi S & 2003 & Japan & 35.69 & 20 & 66 & 1.47 \\
\hline
\end{tabular}


Table 1 Characteristics and research quality of studies reporting the incidence (average per 100,000 over 50 years old), prevalence (average per 100,000 over 50 years old) and mortality (average per 1000 people over 50 years of age) of GCA (Continued)

\begin{tabular}{|c|c|c|c|c|c|c|c|}
\hline Epidemiological study category & First author (citation) & Year & Location & Latitude $\left({ }^{\circ} \mathrm{N}\right)$ & STROBE & Total patients & Rate \\
\hline Prevalence & Martinez PJM & 2016 & Argentina & -34.60 & - & 90 & 120 \\
\hline Prevalence & Pamuk ON & 2009 & Turkey & 41.68 & 20 & 19 & 20 \\
\hline Prevalence & Romero-Gomez C & 2015 & Spain & 36.51 & 21 & 29 & 12.2 \\
\hline Incidence & Abdul-Rahan AM & 2011 & New Zealand & -46.47 & 20 & 70 & 12.73 \\
\hline Incidence & Baldursson $\mathrm{O}$ & 1994 & Iceland & 64.13 & 18 & 133 & 27 \\
\hline Incidence & Bas-Lando M & 2007 & Israel & 31.77 & 19 & 206 & 11.3 \\
\hline Incidence & Bengtsson BA & 1981 & Sweden & 57.70 & 18 & 126 & 28.6 \\
\hline Incidence & Boesen P & 1987 & Denmark & 55.33 & 20 & 46 & 76.6 \\
\hline Incidence & Brekke LK & 2017 & Norway & 60.39 & - & 881 & 16.8 \\
\hline Incidence & Brekke LK & 2015 & Norway & 60.39 & - & 820 & 15.7 \\
\hline Incidence & Bustamante ME & 2004 & Spain & 41.39 & 21 & 55 & 4.1 \\
\hline Incidence & Catanoso M & 2014 & Italy & 44.70 & 21 & 285 & 3.3 \\
\hline Incidence & Catanoso M & 2017 & Italy & 44.70 & 21 & 285 & 7.8 \\
\hline Incidence & Chandran AK & 2015 & USA & 43.83 & 21 & 74 & 19.8 \\
\hline Incidence & Dadoniene J & 2005 & Lithuania & 54.69 & 18 & 11 & 0.72 \\
\hline Incidence & Devauchelle-Pensec V & 2018 & France & 45.76 & 21 & 241 & 8.5 \\
\hline Incidence & Diamantopoulos AP & 2014 & Norway & 58.14 & - & 135 & 17.2 \\
\hline Incidence & Dunstan E & 2014 & Australia & -34.93 & - & 314 & 3.2 \\
\hline Incidence & Elfving $P$ & 2016 & Finland & 62.89 & 20 & 8 & 7.5 \\
\hline Incidence & Friedman G & 1982 & Israel & 31.77 & 20 & 46 & 0.49 \\
\hline Incidence & Gonzalez-Gay MA & 2003 & Spain & 43.01 & 20 & 210 & 9.75 \\
\hline Incidence & Gonzalez-Gay MA & 1992 & Spain & 43.01 & 20 & 255 & 6 \\
\hline Incidence & Gonzalez-Gay MA & 1997 & Spain & 43.01 & 21 & 93 & 9.38 \\
\hline Incidence & Gonzalez-Gay MA & 1999 & Spain & 43.01 & 20 & 110 & 14.1 \\
\hline Incidence & Gonzalez-Gay MA & 2001 & Spain & 43.01 & 20 & 161 & 10.24 \\
\hline Incidence & Gonzalez-Gay MA & 2007 & Spain & 43.01 & 19 & 255 & 10.13 \\
\hline Incidence & Gran JT & 1997 & Norway & 58.83 & 20 & 66 & 29 \\
\hline Incidence & Haugeberg G & 1998 & Norway & 58.83 & 20 & 42 & 27.9 \\
\hline Incidence & Haugeberg G & 2003 & Norway & 58.83 & 18 & 70 & 32.4 \\
\hline Incidence & Huston KA & 1978 & USA & 43.83 & 21 & 42 & 11.7 \\
\hline Incidence & Ing EB & 2019 & Canada & 44.23 & 21 & 35 & 4.9 \\
\hline Incidence & Jonasson F & 1979 & UK & 55.90 & - & 136 & 4.2 \\
\hline Incidence & Khalifa M & 2009 & Tunisia & 35.83 & 20 & 96 & 7 \\
\hline Incidence & Machado EBV & 1988 & USA & 43.83 & 19 & 94 & 17 \\
\hline Incidence & Mader T & 2009 & USA & 61.22 & 19 & 122 & 1.02 \\
\hline Incidence & Martinez PJM & 2016 & Argentina & -34.60 & - & 90 & 8.6 \\
\hline Incidence & Mohammad A & 2011 & Sweden & 55.99 & - & 840 & 11.3 \\
\hline Incidence & Mohammad AJ & 2015 & Sweden & 55.99 & - & 840 & 14.1 \\
\hline Incidence & Mollan SP & 2015 & UK & 52.49 & 17 & 7864 & 4.31 \\
\hline Incidence & Nesher G & 2016 & Israel & 31.77 & 20 & 140 & 8.1 \\
\hline Incidence & Nordborg C & 2003 & Sweden & 57.70 & 20 & 665 & 22.2 \\
\hline Incidence & Nordborg E & 1989 & Sweden & 57.70 & 18 & 284 & 18.3 \\
\hline Incidence & Pamuk ON & 2009 & Turkey & 41.68 & 21 & 19 & 1.13 \\
\hline
\end{tabular}


Table 1 Characteristics and research quality of studies reporting the incidence (average per 100,000 over 50 years old), prevalence (average per 100,000 over 50 years old) and mortality (average per 1000 people over 50 years of age) of GCA (Continued)

\begin{tabular}{|c|c|c|c|c|c|c|c|}
\hline Epidemiological study category & First author (citation) & Year & Location & Latitude $\left({ }^{\circ} \mathrm{N}\right)$ & STROBE & Total patients & Rate \\
\hline Incidence & Petri $\mathrm{H}$ & 2015 & UK & 55.90 & 20 & 4671 & 11.2 \\
\hline Incidence & Petursdottir V & 1999 & Sweden & 57.70 & 19 & 665 & 22.2 \\
\hline Incidence & Potocnik N & 2014 & Slovenia & 46.06 & - & 97 & 8.7 \\
\hline Incidence & Potocnik N & 2018 & Slovenia & 46.06 & - & 169 & 10.5 \\
\hline Incidence & Pucelji NP & 2018 & Slovenia & 46.06 & 21 & 169 & 8.7 \\
\hline Incidence & Rajala SA & 1993 & Finland & 61.50 & 20 & 66 & 7.2 \\
\hline Incidence & Ramstead C & 2007 & Canada & 52.13 & 19 & 141 & 9.4 \\
\hline Incidence & Reinhold-Keller E & 2000 & Germany (north) & 54.21 & 20 & 180 & 8.7 \\
\hline Incidence & Reinhold-Keller E & 2000 & Germany (south) & 48.66 & 20 & 180 & 9.4 \\
\hline Incidence & Richier Q & 2018 & France & 44.29 & - & 60 & 2.33 \\
\hline Incidence & Romero-Gomez C & 2015 & Spain & 36.51 & 21 & 29 & 2.2 \\
\hline Incidence & Salvarani C & 1991 & Italy & 44.70 & 20 & 43 & 6.9 \\
\hline Incidence & Salvarani C & 1995 & USA & 43.83 & 18 & 125 & 17.8 \\
\hline Incidence & Salvarani C & 2004 & USA & 44.70 & 20 & 173 & 18.8 \\
\hline Incidence & Schmidt D & 2001 & & 45.44 & 20 & 99 & 2.07 \\
\hline Incidence & Smeeth L & 2006 & UK & 52.49 & 20 & 3928 & 8.42 \\
\hline Incidence & Smith CA & 1983 & USA & 31.96 & 18 & 26 & 1.58 \\
\hline Incidence & Sonnenblick M & 1994 & Israel & 31.77 & 20 & 84 & 10.2 \\
\hline Incidence & Tam & 2008 & Hong Kong & 22.40 & 19 & 47 & 0.34 \\
\hline Incidence & Udayakumar PD & 2013 & USA & 43.83 & - & 39 & 19.25 \\
\hline Incidence & Yates M & 2013 & UK & 52.63 & 21 & 119 & 6.8 \\
\hline
\end{tabular}

Note: Latitude was determined for regions within a country where a study population was taken

compared to 61 that reported on incidence. We expect both incidence and prevalence of GCA would have similar associations with latitude if there were more studies and an analysis of more areas within the world so latitude could be sufficient sufficiently explored for the prevalence in GCA.

With respect to temporal trends, incidence rates globally were found to generally decrease over time, with some regional differences. Specifically, North America, South America, and Europe had stable incidence rates over time, whereas rates in Scandinavia decreased. The downward trend in Scandinavia may be explained by changes in immigration. Immigration to Sweden has been steadily rising since 2008, reaching record high numbers in 2013 [10]. As of 2017, Statistics Sweden reported that around 2,439,007 or $24 \%$ of Swedish residents were foreign born [19] Most of these immigrants originated from Asian and Middle Eastern countries, where rates of GCA are among the lowest [20]. Denmark and Norway similarly underwent increases in immigration, albeit with lower numbers [13]. The timeframe over which these increases in immigration occurred coincides with when the decreasing trends in incidence of GCA began (approximately 2011, according to our data). This trend is in sharp contrast with previous epidemiological studies published prior to 2011, which showed increasing incidence over time across Scandinavia and other parts of Europe [9, 11, 12].

We expect total numbers of cases to begin increasing in the future as the population ages.

Mortality in GCA was found to generally decrease over time, and showed no geographic variation. The decrease in mortality can likely be explained by overall increased longevity in the elderly, earlier diagnoses, increased surveillance, and earlier initiation of therapy as well as possibly the use of steroid-sparing treatments such as methotrexate. We had insufficient data to analyze the SMR and cannot comment if the mortality relative to the age-/gender-matched population is changing. Controversy exists surrounding studies with an increased mortality in GCA [1, 11, 21-23].

Our study is not without limitations. There is a lack of a standardized definition of GCA used consistently in the literature, resulting in the inclusion of heterogeneous data in our analysis. This inconsistency is 


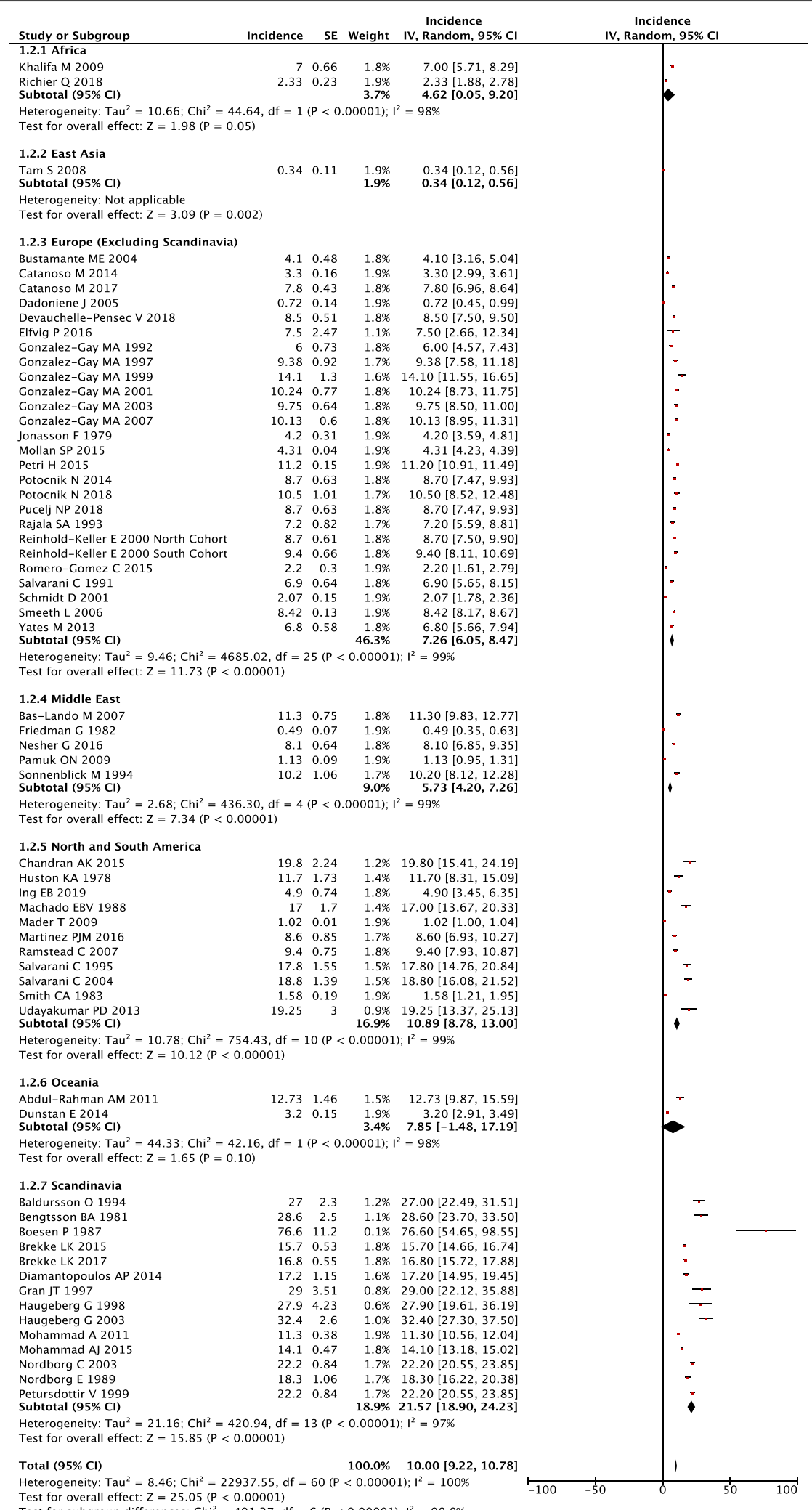

Fig. 2 Forest plot of incidence of giant cell arteritis across geographic regions 


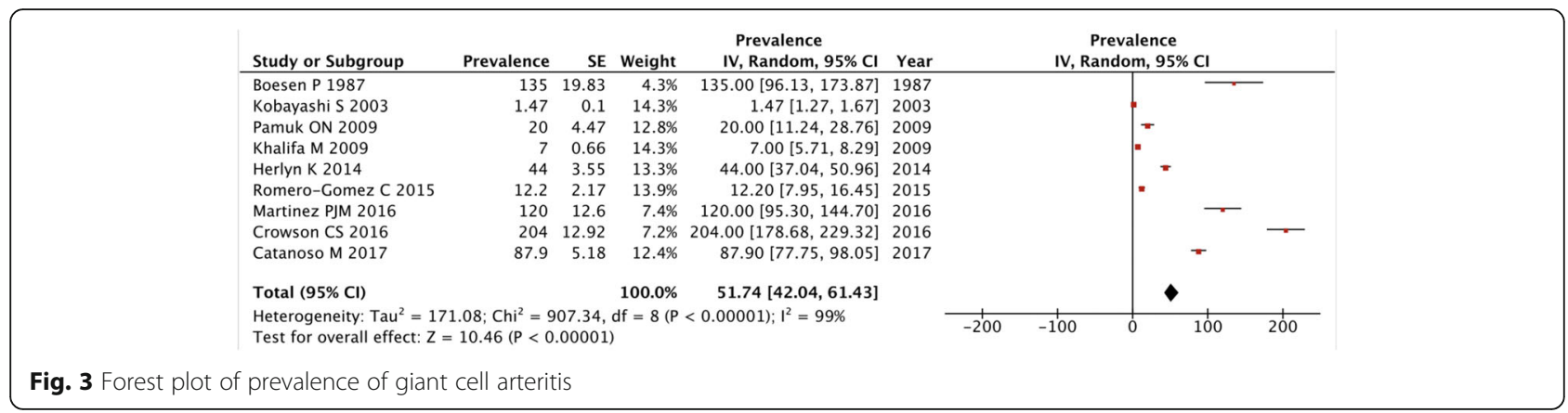

evident in administrative databases, where the lack of a specific billing code for GCA can misclassify patients and either over- or underestimate data [24]. Another consequence is that inclusion criteria were inconsistently used in the study selection process. As previously mentioned, the 1990 ACR criteria do not mandate biopsy positive results. Thus, the majority of hospitalbased studies included only biopsy-proven cases, whereas most population or community-based studies included also clinical diagnoses. Therefore, data may be vary depending on which inclusion criteria was used. Non-English studies were also excluded. Finally, some

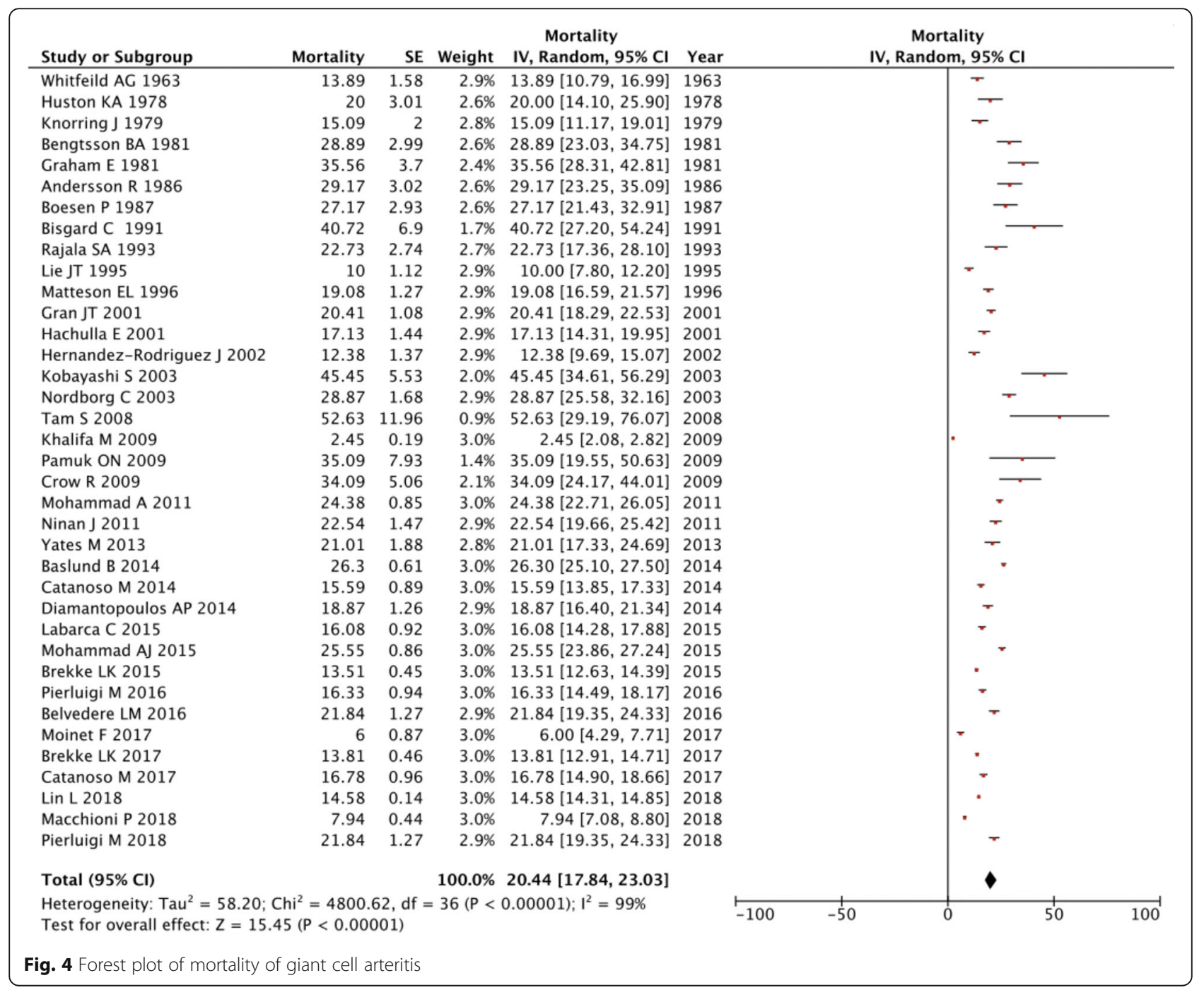


a.

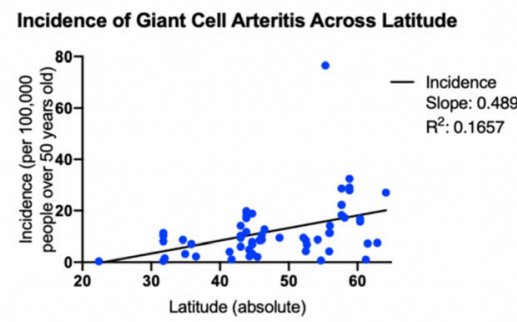

b.

Prevalence of Giant Cell Arteritis Across Latitude

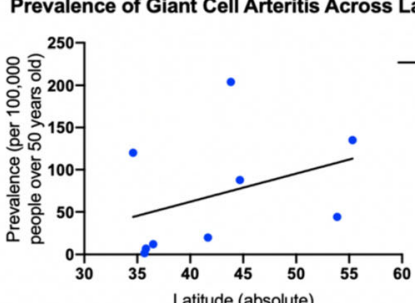

c.

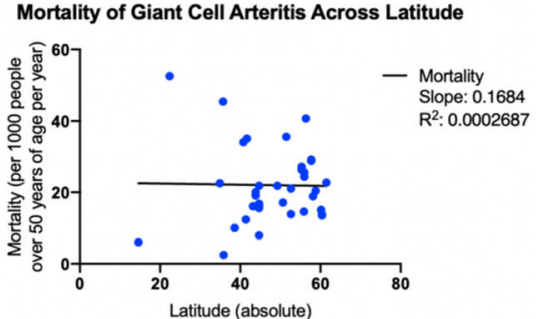

Fig. 5 Incidence, prevalence, and mortality of giant cell arteritis across latitude

studies on mortality combined data for both PMR and GCA, which would have falsely deflated the reported mortality rates since PMR has a lower mortality rate than GCA [25].

\section{Conclusion}

This study demonstrates epidemiological trends in GCA with a comprehensive description of updated global pooled incidence, prevalence, and mortality of GCA. Incidence rates vary significantly between regions and are highest in Scandinavia. Temporally, GCA incidence and mortality decreased, while prevalence remained stable. Latitude does influence incidence but not prevalence or mortality in GCA although the results may be underpowered for comparing prevalence and latitude in GCA.

\section{Supplementary Information}

The online version contains supplementary material available at https://doi. org/10.1186/s13075-021-02450-w.

Additional file 1: Supplementary Table 1. Search terms used for determining the incidence, prevalence and mortality of giant cell arteritis. Supplementary Figure 1. Funnel Plots of Incidence, Prevalence and Mortality of Giant Cell Arteritis. Supplementary Figure 2. Global Incidence of Giant Cell Arteritis on the World Map.

Additional file 2: Supplementary Table 2. STROBE asssessment of the included trials.

\section{Abbreviations}

ACR: American college of rheumatology; GCA: Giant Cell Arteritis; PMR: Polymyalgia rheumatica; SMR: Standardized mortality ratio; STROBE: Strengthening the Reporting of Observational Studies in Epidemiology; TAB: Temporal artery biopsy

\section{Acknowledgements}

We would like to thank all the support staff at St. Joseph's Health Care.

\section{Authors' contributions}

$\mathrm{KL}$ and DS were responsible for manuscript writing, data analysis, and experimental design. MT was responsible for statistical analysis and manuscript editing. JP was responsible for experimental design and manuscript editing. The authors read and approved the final manuscript.

\section{Funding}

Daniel Semenov was a Canadian Rheumatology Association Summer Student. There was no other funding for the study.
Availability of data and materials

Raw data is presented in Table 1 and Supplementary Table 1. Further information is available upon reasonable request.

Ethics approval and consent to participate

Ethics approval was not required as this is a systematic review. Not applicable.

Consent for publication

This study contains no personal patient data. Not applicable.

\section{Competing interests}

None to declare.

\section{Author details}

${ }^{1}$ Schulich School of Medicine, University of Western Ontario, St. Joseph's Health Care, 268 Grosvenor St, D2 Rheumatology, London, ON N6A 4V2, Canada. ${ }^{2}$ University College Dublin, School of Medicine and Medical Sciences, Dublin 4, Ireland.

Received: 6 November 2020 Accepted: 11 February 2021

Published online: 11 March 2021

\section{References}

1. Nordborg E, Nordborg C. Giant cell arteritis: epidemiological clues to its pathogenesis and an update on its treatment. Rheumatology. 2003;42(3): 413-21 https://doi.org/10.1093/rheumatology/keg116.

2. Piggott K, Biousse V, Newman NJ, Goronzy JJ, Weyand CM. Vascular damage in giant cell arteritis. Autoimmunity. 2009;42(7):596-604. https://doi.org/10.1 080/08916930903002495

3. Baig IF, Pascoe AR, Kini A, Lee AG. Giant cell arteritis: early diagnosis is key. Eye Brain. 2019;11:1-12. Published 2019 Jan 17. doi:https://doi.org/10.2147/ EB.S170388

4. Charlton R. Optimal management of giant cell arteritis and polymyalgia rheumatica. Ther Clin Risk Manag. 2012;8:173-9. https://doi.org/10.2147/ TCRM.S13088.

5. Kermani TA, Schäfer VS, Crowson CS, et al. Increase in age at onset of giant cell arteritis: a population-based study. Ann Rheum Dis. 2010;69:780-1.

6. Marília A. Dagostin and Rosa M.R. Pereira (January 28th 2020). Giant cell arteritis: current advances in pathogenesis and treatment [online first], IntechOpen, DOI: https://doi.org/10.5772/intechopen.91018. Available from: https://www.intechopen.com/online-first/giant-cell-arteritis-current-adva nces-in-pathogenesis-and-treatment

7. Alonso A, Hernán MA. Temporal trends in the incidence of multiple sclerosis: a systematic review. Neurology. 2008;71(2):129-35. https://doi. org/10.1212/01.wnl.0000316802.35974.34.

8. Richard A. Watts, 2. Epidemiology of giant cell arteritis: a critical review, Rheumatology, Volume 53, Issue suppl_2, July 2014, Pages i1-i2, https://doi. org/10.1093/rheumatology/keu183.

9. Nordborg C, Johansson H, Petursdottir V, Nordborg E. The epidemiology of biopsy-positive giant cell arteritis: special reference to changes in the age of the population. Rheumatol (Oxf). 2003;42:549-52.

10. Andersson, R, Weinar, A. Integration policies : Sweden country report. Migration Policy Centre, INTERACT Research Report, Country Reports. Updated 
2014. Retrieved from Cadmus, European University Institute Research Repository, at: http://hdl.handle.net/1814/32656

11. Gonzalez-Gay MA, Miranda-Filloy JA, Lopez-Diaz MJ, PerezAlvarez R, Gonzalez-Juanatey C, Sanchez-Andrade A, Martin J, Llorca J. Giant cell arteritis in northwestern Spain: a 25-year epidemiologic study. Medicine (Baltimore). 2007:86:61-8.

12. Petursdottir V, Johansson H, Nordborg E, Nordborg C. The epidemiology of biopsy-positive giant cell arteritis: special reference to cyclic fluctuations. Rheumatol (Oxf). 1999;38:1208-12.

13. Moore H. Immigration in Denmark and Norway: protecting culture or protecting rights? Scand Stud. 2010;82(3):355-64 Retrieved May 28, 2020, from www.jstor.org/stable/25769037.

14. Lee JL, Naguwa SM, Cheema GS, Gershwin ME. The geo-epidemiology of temporal (giant cell) arteritis. Clin Rev Allergy Immunol. 2008;35(1-2):88-95. https://doi.org/10.1007/s1 2016-008-8075-0.

15. Palomino-Morales RJ, Vazquez-Rodriguez TR, Torres O, et al. Association between IL-18 gene polymorphisms and biopsy-proven giant cell arteritis. Arthritis Res Ther. 2010;12(2):R51. https://doi.org/10.1186/ar2962.

16. Weyand C, Goronzy J. Immune mechanisms in medium and large-vessel vasculitis. Nat Rev Rheumatol. 2013;9:731-40 https:/doi.org/10.1038/ nrrheum.2013.161.

17. Brekke LK, Fevang BT, Myklebust G. Increased incidence of Giant cell arteritis in urban areas? J Rheumatol. 2019;46(3):327-8. https://doi.org/10.3899/ jrheum.180714https://www.ncbi.n/m.nih.gov/books/NBK459376/.

18. Mackie SL, Taylor JC, Haroon-Rashid L, et al. Association of HLA-DRB1 amino acid residues with giant cell arteritis: genetic association study, metaanalysis and geo-epidemiological investigation. Arthritis Research Therapy. 2015;17:175 https://doi.org/10.1186/s13075-015-0692-4

19. Summary of Population Statistics 1960-2019. Statistics Sweden website. Updated March 19, 2020. . https://www.scb.se/en/finding-statistics/statisticsby-subject-area/population/population-composition/population-statistics/ pong/tables-and-graphs/yearly-statistics\%2D\%2Dthe-whole-country/summa ry-of-population-statistics/

20. Foreign citizens by country of citizenship, age and sex. Year 1973-2019. Statistics Sweden website. Accessed May 27, 2020. http://www.statistikdata basen.scb.se/pxweb/en/ssd/START_BE_BE0101_BE0101F/UtlmedbR/ ?rxid=b83e5bbd-958a-4655-aa40-486ba2ca09a3

21. Ben-Shabat N, Tiosano S, Shovman O, et al. Mortality among patients with giant-cell arteritis: A large-scale population-based cohort study [published online ahead of print, 2019 Dec 15]. J Rheumatol. 2019;jrheum.190927. doi: https://doi.org/10.3899/jrheum.190927

22. Bisgård C, Sloth $\mathrm{H}$, Keiding N, Juel $\mathrm{K}$. Excess mortality in giant cell arteritis. J Intern Med. 1991;230(2):119-23. https://doi.org/10.1111/j.1365-2796.1991. tb00418.x.

23. Crow RW, Katz BJ, Warner JE, et al. Giant cell arteritis and mortality. J Gerontol A Biol Sci Med Sci. 2009;64(3):365-9. https://doi.org/10.1093/ gerona/gln030.

24. Bara L, Pope JE, Pequeno P, Saxena FE, Bell M, Haaland D, Widdifield J. Incidence and prevalence of giant cell arteritis in Ontario, Canada. Rheumatology (Oxford). 2020;27(8):2927-48. https://doi.org/10.1093/rheuma tology/keaa095.

25. Uddhammar A, Eriksson A-L, Nyström L, et al. Increased mortality due to cardiovascular disease in patients with giant cell arteritis in northern Sweden. J Rheumatol. 2002;29(4):737-42.

\section{Publisher's Note}

Springer Nature remains neutral with regard to jurisdictional claims in published maps and institutional affiliations.

Ready to submit your research? Choose BMC and benefit from:

- fast, convenient online submission

- thorough peer review by experienced researchers in your field

- rapid publication on acceptance

- support for research data, including large and complex data types

- gold Open Access which fosters wider collaboration and increased citations

- maximum visibility for your research: over $100 \mathrm{M}$ website views per year

At BMC, research is always in progress.

Learn more biomedcentral.com/submissions 